WHEN THE SAHARA WAS GREEN 



\section{WHEN THE SAHARA WAS GREEN}

HOW OUR GREATEST DESERT CAME TO BE

\section{MARTIN WILLIAMS}




\section{Copyright (C) 2021 by Princeton University Press}

Princeton University Press is committed to the protection of copyright and the intellectual property our authors entrust to us. Copyright promotes the progress and integrity of knowledge. Thank you for supporting free speech and the global exchange of ideas by purchasing an authorized edition of this book. If you wish to reproduce or distribute any part of it in any form, please obtain permission.

Requests for permission to reproduce material from this work should be sent to permissions@press.princeton.edu

Published by Princeton University Press

41 William Street, Princeton, New Jersey o8540

6 Oxford Street, Woodstock, Oxfordshire OX20 1TR

press.princeton.edu

All Rights Reserved

ISBN 9780691201627

ISBN (e-book) 9780691228891

British Library Cataloging-in-Publication Data is available

Editorial: Ingrid Gnerlich \& María García

Production Editorial: Ali Parrington

Text and Jacket Design: Karl Spurzem

Production: Danielle Amatucci

Publicity: Sara Henning-Stout \& Kate Farquhar-Thomson

Copyeditor: Karen Verde

Endpapers, inside front cover: Map of major Saharan localities; inside back cover: Map of Saharan and adjacent countries

This book has been composed in Arno

Printed on acid-free paper. $\infty$

Printed in the United States of America

$\begin{array}{llllllllll}10 & 9 & 8 & 7 & 6 & 5 & 4 & 3 & 2 & 1\end{array}$ 
In memory of Françoise Gasse, Théodore Monod, and Pascal Lluch: You shared my love and respect for our greatest desert. Valete! 
